\title{
Effect of Structure on the Storage Characteristics of Manganese Oxide
}

\section{Electrode Materials}

\author{
Yong Joon Park ${ }^{1,2}$ and Marca M. Doeff ${ }^{1}$ \\ 1) Materials Sciences Division \\ Lawrence Berkeley National Laboratory \\ University of California \\ Berkeley, CA 94720 USA \\ and
}

2) Ionics Device Team, Electronics and Telecommunications Research Institute

161 Gajeong-dong, Yuseong-gu, Daejeon, 305-350, KOREA

\section{Acknowledgment}

This work was supported by the Assistant Secretary for Energy Efficiency and

Renewable Energy, Office of FreedomCAR and Vehicle Technologies of the U.S.

Department of Energy under contract no. DE-AC02-05CH11231. This work was also supported by the Korea Research Foundation Grant (M01-2004-000-20008-0) (YJP). 


\begin{abstract}
Eleven types of manganese-containing electrode materials were subjected to longterm storage at $55^{\circ} \mathrm{C}$ in $1 \mathrm{M} \mathrm{LiPF}_{6}$ ethylene carbonate/dimethyl carbonate (EC/DMC) solutions. The amount of manganese dissolution observed depended upon the sample surface area, the average Mn oxidation state, the structure, and substitution levels of the manganese oxide. In some cases, structural changes such as solvate formation were exacerbated by the high temperature storage, and contributed to capacity fading upon cycling even in the absence of significant Mn dissolution. The most stable materials appear to be Ti-substituted tunnel structures and mixed metal layered oxides with $\mathrm{Mn}$ in the +4 oxidation state.
\end{abstract}

Keywords: Manganese oxides, cathode materials, storage at $55^{\circ} \mathrm{C}$, manganese dissolution 


\section{Introduction}

The manganese oxide system is polymorphous, and includes a wide variety of spinel, layered, and tunnel-containing structures. Several of these materials have found use as battery cathodes for either alkaline or Li ion batteries; most notably $\gamma-\mathrm{MnO}_{2}$ and spinels related to $\mathrm{LiMn}_{2} \mathrm{O}_{4}$. In the case of the latter, widespread commercial use in lithium ion cells has been inhibited by its tendency to undergo dissolution into the electrolytic solution, which often contains HF or other protic components, at elevated temperatures. To address this problem, several approaches have been used, including the use of protective coating on particle surfaces $[1,2,3]$ and the development of new electrolyte salts that do not form acidic species in solution $[4,5,6]$. One of the most intriguing observations is the fact that there is a drastic reduction in Mn dissolution when spinel is combined with another cathode material such as $\mathrm{LiNi}_{0.4} \mathrm{Co}_{0.3} \mathrm{Mn}_{0.3} \mathrm{O}_{2}$ in a lithium ion battery configuration [7]. This suggests that the Mn dissolution phenomenon is not necessarily intrinsic to all manganesecontaining oxides. Certainly, the electrochemical behavior of manganese oxides varies greatly with structure [8], so it would not be surprising to find that other properties vary as well. Herein, we describe experiments designed to determine how storage and cycling properties vary with structure for selected layered and tunnel-containing manganese oxides. 


\section{Experimental}

Eleven kinds of cathode material were selected for this study. Tunnel-structured manganese oxides having the approximate compositions of $\mathrm{Li}_{0.36} \mathrm{MnO}_{2}, \mathrm{Li}_{0.44} \mathrm{Ti}_{0.44} \mathrm{Mn}_{0.56} \mathrm{O}_{2}$, $\mathrm{Li}_{0.44} \mathrm{Ti}_{0.33} \mathrm{Mn}_{0.67} \mathrm{O}_{2}, \mathrm{Li}_{0.44} \mathrm{Ti}_{0.22} \mathrm{Mn}_{0.78} \mathrm{O}_{2}, \mathrm{Li}_{0.44} \mathrm{Ti}_{0.11} \mathrm{Mn}_{0.89} \mathrm{O}_{2}$ were prepared by ion exchange of $\mathrm{Na}_{\mathrm{x}} \mathrm{Ti}_{\mathrm{y}} \mathrm{Mn}_{1-\mathrm{y}} \mathrm{O}_{2}(\mathrm{y}=0,0.11,0.22,0.33,0.44)$ precursors as previously described. [9] Three types of layered manganese oxides $\left(\mathrm{O} 2-\mathrm{Li}_{0.484} \mathrm{Na}_{0.067} \mathrm{MnO}_{2.02}, \quad \mathrm{O} 3-(\mathrm{Li}\right.$, $\mathrm{Na})_{0.45} \mathrm{Mn}_{0.9} \mathrm{Al}_{0.1} \mathrm{O}_{2}$, and $\left.\mathrm{O} 2 / \mathrm{O} 3-(\mathrm{Li}, \mathrm{Na})_{0.55}-\mathrm{Mn}_{0.96} \mathrm{Al}_{0.04} \mathrm{O}_{2}\right)$ were also selected, and synthesized and ion-exchanged as outlined in references 10 and11. Three commercial powders, $\quad \mathrm{Li}_{1.03} \mathrm{Ni}_{0.51} \mathrm{Mn}_{0.5} \mathrm{O}_{2}$ and $\mathrm{Li}_{1.055} \mathrm{Ni}_{0.334} \mathrm{Co}_{0.336} \mathrm{Ni}_{0.334} \mathrm{O}_{2}$ (Tanaka Chemical Corporation, Osaka, Japan) and Selectipur SP30 $\mathrm{Li}_{1+\mathrm{x}} \mathrm{Mn}_{2-\mathrm{x}} \mathrm{O}_{4} \quad(\mathrm{x} \approx 0.03-0.06)$ (EM Industries, Inc., Hawthorne NY) were also chosen for comparison with the other structures. The surface area of those powders was determined by BET (Brunauer-Emmett-Teller) analysis using a surface area and porosity analyzer (Micromeritics, Tristar).

Well-dried bottles containing $0.2 \mathrm{~g}$ of dried cathode powders and $8 \mathrm{ml}$ of electrolyte (1M LiPF6 in 1: 2 EC-DMC v/v Merck Selectipur lot \#EF268314) were stored at $55^{\circ} \mathrm{C}$ in an inert atmosphere glove box for 8 weeks. Manganese $\left(\mathrm{Mn}^{2+}\right)$ test strips (Merck) were used to check for manganese dissolution of the samples every two weeks. Aliquots of 0.1 
$\mathrm{mL}$ of the electrolyte solutions were removed and placed on the test strips, and two indicators were then added according to the instructions. A color change of the strip from yellow to green was a positive indicator of $\mathrm{Mn}^{2+}$ in solution, with the darkness of the green correlating to the amount of dissolved metal. The same procedure was also carried out on a blank (e.g., electrolyte solution not contacting manganese oxide powder) to make sure that there was no interference from other chemical species. In that case, no color change was noted.

Powders were washed with ethanol and dried after storage and prior to spectroscopic analysis. X-ray powder diffraction patterns were obtained on the cathode materials before and after storage at $55^{\circ} \mathrm{C}$ using a Philips $\mathrm{X}^{\prime}$ Pert diffractometer in the $2 \theta$ range from 10 to $70^{\circ}$ with monochromatized $\mathrm{Cu}-\mathrm{K} \alpha$ radiation. Infrared spectra were obtained on samples before and after storage in $\mathrm{KBr}$ pellets using a BOMEM Fourier transform infrared (FTIR) spectrophotometer.

For the preparation of positive electrodes, $0.5 \mathrm{~g}$ of polyvinyl difluoride (PVdF, Kynar) was dissolved in about $7 \mathrm{~g}$ of N-methyl-2-pyrrolidone for 1 hour and then $3.5 \mathrm{~g}$ of sample powder, $0.5 \mathrm{~g}$ of carbon black and $0.5 \mathrm{~g}$ of SFG- 6 graphite (Timrex Timcal) were added. After 3 hours of mixing, the resultant viscous slurry was coated on an aluminum foil using 
a doctor blade and dried at $100^{\circ} \mathrm{C}$ in a vacuum oven. Electrochemical cells were assembled in a dry box from positive electrodes cut out from the coated foils, lithium metal, Celgard 3401 separators, and $1 \mathrm{M} \mathrm{LiPF}_{6}$ solution in 2:1 ethylene carbonate/dimethyl carbonate (v:v, Merck). Cells were subjected to galvanostatic and potentiostatic cycling using a MacPile II (Bio-Logic,SA, Claix, France) or an Arbin BT/HSP-2043 cycler at both room temperature and $55^{\circ} \mathrm{C}$.

\section{Results and Discussion}

Table 1 summarizes the relevant physical properties of the manganese-containing electrode materials used in this study. Figure 1 summarizes the results of the manganese dissolution tests for the various powders stored in $1 \mathrm{M} \mathrm{LiPF}_{6} \mathrm{EC} / \mathrm{DMC}$ solutions at $55^{\circ} \mathrm{C}$ over 2-8 week periods. The amount and rate of $\mathrm{Mn}^{2+}$ dissolution can be expected to depend not only upon the sample surface area but also the fraction of $\mathrm{Mn}^{3+}$ ions, which can undergo the disproportionation reaction shown below when protonic species are present [12]:

$$
2 \mathrm{Mn}^{3+} \text { (solid) } \rightarrow \mathrm{Mn}^{4+} \text { (solid) }+\mathrm{Mn}^{2+} \text { (solution) }
$$

Thus, it is not surprising that no Mn dissolution occurs for $\mathrm{Li}_{1.03} \mathrm{Ni}_{0.51} \mathrm{Mn}_{0.5} \mathrm{O}_{2}$ 
(LNMO) and $\mathrm{Li}_{1.055} \mathrm{Ni}_{0.334} \mathrm{Co}_{0.336} \mathrm{Ni}_{0.334} \mathrm{O}_{2}(\mathrm{LNCMO})$, in which all $\mathrm{Mn}$ is in the +4 oxidation state $[13,14,15,16]$. In contrast, about $50 \mathrm{ppm} \mathrm{Mn}^{2+}$ is found in solution for the fairly high surface area Li-rich spinel after eight weeks of contact with electrolytic solution; for this material, slightly less than half the $\mathrm{Mn}$ is in the +3 oxidation state.

The behavior of the layered $\mathrm{O} 2, \mathrm{O} 2 / \mathrm{O} 3$ intergrowth, and $\mathrm{O} 3$ manganese oxides does not, however, follow the expected trend. These materials all contain significant fractions of $\mathrm{Mn}^{3+}$ ions and have even higher surface areas than the spinel sample used in this study. Yet, the rate and amount of Mn dissolution varies from essentially none (O2) to nearly 50 ppm dissolved $\mathrm{Mn}^{2+}$ after 8 weeks for the $\mathrm{O} 3$ structure. The tendency towards $\mathrm{Mn}$ dissolution at $55^{\circ} \mathrm{C}$ also varies for compounds with tunnel structures, although this is complicated by the presence of $\mathrm{Mn}_{2} \mathrm{O}_{3}$ impurities in many of the samples (discussion below). Almost no dissolution is seen for $\mathrm{Li}_{0.44} \mathrm{Ti}_{0.44} \mathrm{Mn}_{0.56} \mathrm{O}_{2}$, a tunnel compound in which $44 \mathrm{~mol} \%$ of $\mathrm{Mn}$ is replaced by Ti. Much of the remaining $\mathrm{Mn}$ is, however, in the +3 oxidation state [9]. These observations strongly suggest that structure and, possibly, substitution effects are also important factors in determining the propensity of manganese oxides to undergo dissolution when protonic species are present. As a caveat, it should be noted that differing amounts of water could be introduced into the electrolytic solutions 
when metal oxide powders are added, which would change the concentration of HF. Although reasonable care was taken to ensure that all components were dried thoroughly prior to testing, it can be quite difficult to remove all adsorbed water from these powders, especially those with high surface areas. The fact that some of the lowest dissolution rates were still obtained for the highest surface area materials in this study, however, adds support to the conclusion that different manganese oxide structures vary in their propensity to undergo dissolution.

Peak broadening was seen in the XRD pattern of the $\mathrm{Li}_{1+\mathrm{x}} \mathrm{Mn}_{2-\mathrm{x}} \mathrm{O}_{4}$ spinel after storage (not shown), suggesting a loss of crystallinity and/or decrease in particle size [17]. This is consistent with the observed Mn dissolution in Figure 1a, which leads to the formation of a defect spinel structure [18, 19] and rapid loss of capacity upon cycling [20]. Depending upon the details of the storage experiment (type of electrolytic solution, temperature, state-of-charge, etc.), proton exchange [18], phase separation [20], film formation, and precipitation of $\mathrm{MnO}$ and $\mathrm{MnF}_{2}$ on particle surfaces [21], all of which have an adverse impact on the electrochemical characteristics, may also occur. The behavior of the spinel in contact with electrolytic solutions at elevated temperatures has been covered extensively in the literature and is not further considered here. 
The most dramatic changes induced by elevated temperature storage were observed in layered $\mathrm{O} 2-\mathrm{Li}_{0.484} \mathrm{Na}_{0.067} \mathrm{MnO}_{2.02}$, in spite of the low Mn dissolution, as seen in the XRD patterns presented in Figure 2a. Peaks in the patterns of the dried compound before exposure are broad due to stacking faults induced by the presence of residual sodium between some of the layers [22]. In addition, a weak reflection due to unexchanged P2$\mathrm{Na}_{0.7} \mathrm{MnO}_{2+z}$ precursor material is evident. After storage in solution, the pattern of the O2$\mathrm{Li}_{0.484} \mathrm{Na}_{0.067} \mathrm{MnO}_{2.02}$ shows a series of prominent very broad peaks overlapping the precursor reflection at low angles, and a second very strong broad peak near $2 \theta=22.4^{\circ}$. Those at low angles are strongly reminiscent of 002 reflections belonging to hydrated phases found in samples exposed to the atmosphere; see middle pattern in Figure 2a. In the hydrates, water is inserted between the transition metal layers, causing increases in the dspacings [22]. This water can be removed readily by drying samples above $100^{\circ} \mathrm{C}$, but the O2-hydrates re-form rapidly (often within just a few hours) after re-exposure to the atmosphere.

These results indicate that solvated phases, in which components of the electrolytic solution are inserted between the transition metal layers of $\mathrm{O} 2-\mathrm{Li}_{0.484} \mathrm{Na}_{0.067} \mathrm{MnO}_{2.02}$, form 
during storage. This effect is unlikely to be due solely to residual water, considering the intensities of the reflections.

The peak near $2 \theta=22.4^{\circ}$ is evident in the pattern of the $\mathrm{O} 2$ phase exposed to air (middle of Figure 2a), but it is much weaker than that seen in the pattern of the same material stored for eight weeks in electrolytic solution (top of Figure 2a). This is most likely an as-yet unidentified decomposition product resulting from exfoliation of the greatly expanded solvate or hydrate phases.

As with $\mathrm{O} 2-\mathrm{Li}_{0.484} \mathrm{Na}_{0.067} \mathrm{MnO}_{2.02}, \mathrm{Mn}$ dissolution for the $\mathrm{O} 2 / \mathrm{O} 3$ intergrowth compound $(\mathrm{Li}, \mathrm{Na})_{0.55} \mathrm{Mn}_{0.96} \mathrm{Al}_{0.04} \mathrm{O}_{2}$ in electrolytic solution at elevated temperatures is minimal (Figure 1a). The intergrowth also forms hydrates or solvates upon storage but to a markedly lesser extent than for $\mathrm{O}_{2}-\mathrm{Li}_{0.484} \mathrm{Na}_{0.067} \mathrm{MnO}_{2.02}$ (Figure 2b) and there is no evidence of a decomposition product due to exfoliation. However, the relative intensities of hol reflections between $2 \theta=35-50^{\circ}$ change markedly. In particular, those attributable to the $\mathrm{O} 2$ fraction become more prominent while those attributable to $\mathrm{O} 3$ decrease. It is unlikely that $\mathrm{O} 2$ will convert to $\mathrm{O} 3$ under these conditions [22], instead, a re-orientation of the two components with respect to one another and/or preferential hydration/solvation of one component may be responsible for the observed changes. 
The behavior of the $\mathrm{O} 3$ compound selected for this study ((Li,Na) $\left.)_{0.45} \mathrm{Mn}_{0.9} \mathrm{Al}_{0.1} \mathrm{O}_{2}\right)$ upon storage is quite different from that of the examples with $\mathrm{O} 2$ or $\mathrm{O} 2 / \mathrm{O} 3$ stacking arrangements. Mn dissolution in electrolytic solution at elevated temperature is much more significant, formation of hydrates occurs only after long-term exposure to the atmosphere (several months), and solvate phases are not detectable in the sample stored in electrolytic solution (Figure 2c).

The O3 compound resembles spinel manganese oxide in terms of both $\mathrm{Mn}$ dissolution and resistance to solvate formation. This is perhaps not too surprising, because spinel and $\mathrm{O} 3$ compounds are structurally related; both have nearly cubic close-packed arrays of oxygen, with only the distributions of lithium and transition metal cations varying. In fact, $\mathrm{O} 3$ structures readily convert to spinels upon electrochemical cycling; $\mathrm{Mn}^{2+}$ produced from $\mathrm{Mn}^{3+}$ ions via disproportionation diffuse easily through tetrahedral sites into vacancies in the lithium layer [23]. The dissolution results suggest that $\mathrm{Mn}^{2+}$ has an enhanced mobility in this stacking arrangement compared to $\mathrm{O} 2$ or intergrowth structures. The movement of comparatively more $\mathrm{Mn}^{2+}$ ions into the van der Waal's gaps during storage may then effectively prevent expansion of the layers to accommodate solvent or water in $\mathrm{O} 3$ structures. 
The XRD patterns of the $\mathrm{O} 2$ and $\mathrm{O} 2 / \mathrm{O} 3$ compounds exposed to air for prolonged periods show reflections that can be assigned to $\mathrm{Li}_{2} \mathrm{CO}_{3}$ impurity. These are not apparent in the patterns of the freshly prepared and dried materials, suggesting that oxidation takes place upon long-term exposure to air. While $\mathrm{Li}_{2} \mathrm{CO}_{3}$ is not seen in the XRD pattern of the O3 compound exposed to air, it can be detected in the FTIR spectrum (Figure 3), although it is not seen in the material exposed to the electrolytic solution. In the as-prepared materials, the average oxidation state of $\mathrm{Mn}$ is somewhat higher in $\mathrm{O} 3$ compounds than in $\mathrm{O} 2$ or $\mathrm{O} 2 / \mathrm{O} 3$ intergrowths (Table 1), rendering it somewhat less susceptible to air oxidation.

Cycling data at room temperature and $55^{\circ} \mathrm{C}$ for lithium cells containing the three types of layered manganese oxides is presented in Figure 4. In all cases, higher capacities are obtained initially at $55^{\circ} \mathrm{C}$ than at room temperature. This is likely due to an enhanced rate of lithium diffusion. For the $\mathrm{O} 3$ cathode, there is an initial rise in capacity both at room temperature and $55^{\circ} \mathrm{C}$ as the structure converts to spinel, but decreases occur after about 10 cycles. The rapid capacity loss is associated with volume changes induced by the conversion of spinel to a Jahn-Teller distorted tetragonal phase upon deep discharge [24]. At elevated temperatures, phenomena associated with Mn dissolution also can contribute to 
the observed fading. The storage tests suggest that dissolution is less likely to be an issue for $\mathrm{O} 2$ or intergrowth electrode materials (although how this varies with state-of-charge is, as yet, unknown). Instead, solvate formation and exfoliation leading to decomposition of the active materials, are the probable main causes for the observed capacity losses observed during cycling at room temperature and $55^{\circ} \mathrm{C}$. For the intergrowth, Mn dissolution contributes to the increased capacity fading seen at the higher temperature.

XRD patterns of $\mathrm{Li}_{1.03} \mathrm{Ni}_{0.51} \mathrm{Mn}_{0.5} \mathrm{O}_{2}$ (LNMO) and $\mathrm{Li}_{1.055} \mathrm{Ni}_{0.334} \mathrm{Co}_{0.336} \mathrm{Mn}_{0.334} \mathrm{O}_{2}$ (LNCMO) before and after exposure to electrolytic solution at $55^{\circ} \mathrm{C}$ are presented in Figures $5 \mathrm{a}$ and $\mathrm{b}$, respectively. These compounds have $\mathrm{O} 3$ stacking arrangements, but are not susceptible to $\mathrm{Mn}$ dissolution because all the $\mathrm{Mn}$ ions are in the +4 oxidation state. Hydrate formation does not occur, and $\mathrm{Li}_{2} \mathrm{CO}_{3}$ is not detected in either the XRD patterns or FTIR spectra of powders exposed to air or solution. Nevertheless, weak peaks attributable to solvate phases can be observed in the pattern of LNMO stored in electrolyte at $55^{\circ} \mathrm{C}$ (Figure 5a). Additionally, a broad peak located near $2 \theta=22.5^{\circ}$ is also visible in the pattern of stored LNCMO. This is not associated with solvate formation, as the low angle peaks characteristic of expanded phases are not observed. Instead, it is likely that an amorphous component of the LNCMO powder crystallizes or reacts under the conditions of the storage 
experiment. The FTIR spectrum (Figure 6) of the original dry LNCMO powder also shows peaks indicative of an organic constituent such as an ester, salt of an ester, or an alkyl carbonate compound $\left(v_{\mathrm{C}-\mathrm{H}} 2966,2926,2860 \mathrm{~cm}^{-1}, v_{\mathrm{C}=\mathrm{O}} 1733 \mathrm{~cm}^{-1}, \delta_{\mathrm{CH} 2} 1466 \mathrm{~cm}^{-1}, v_{\mathrm{C}-\mathrm{O}}\right.$ $1125,1075 \mathrm{~cm}^{-1}, \delta_{\mathrm{CH} 3} 1283 \mathrm{~cm}^{-1}$, etc.), which disappear after storage and washing. This constituent must originate from the original preparation, because the spectrum was acquired before any contact with electrolytic solution. Other than these phenomena, the parent LNMO and LNCMO phases appear to be stable during the long contact with electrolytic solution, with no discernible peak broadening and very little alteration in the unit cell parameters. The relative resistance to storage-associated change is reflected in the cycling behavior of these compounds, both at room temperature and $55^{\circ} \mathrm{C}$ (Figure 7), in which little capacity fading is observed.

The excellent cycling stability of tunnel compounds with the $\mathrm{Na}_{0.44} \mathrm{MnO}_{2}$ structure using liquid electrolytes at room temperature, or polymer electrolytes at elevated temperatures has been previously noted [25]. Dissolution at elevated temperature in liquid electrolytes is, however, so significant ( $\sim 5-20 \mathrm{ppm} \mathrm{Mn}^{2+}$ after two weeks) for unsubstituted $\mathrm{Li}_{0.36} \mathrm{MnO}_{2}$ that the storage test was terminated early. The sample whose XRD pattern is presented in Figure $8 \mathrm{a}$ and b originally contained approximately 4 vol. $\% \mathrm{Mn}_{2} \mathrm{O}_{3}$, an 
impurity commonly associated with the parent tunnel- $\mathrm{Na}_{0.44} \mathrm{MnO}_{2} \cdot \mathrm{Mn}_{2} \mathrm{O}_{3}$ dissolves readily in acid and most likely made a major contribution to the results of the Mn strip test. The peak broadening evident in the pattern taken after two weeks of storage (especially observable in the expansion of the mid-angle region shown in Figure 8b) suggests, however, that some of the dissolved $\mathrm{Mn}^{2+}$ originates from $\mathrm{Li}_{0.36} \mathrm{MnO}_{2}$ itself. The unit cell parameters are largely unaffected by this phenomenon. Dissolution of Mn is likely to result in an overall loss of electroactive material rather than formation of defect structures in the case of tunnel compounds. This loss is responsible for slight capacity fading upon cycling at elevated temperatures.

Progressively less Mn dissolution is observed as $\mathrm{Ti}$ substitution in the tunnel structure is increased (Figure 1), although several of these compounds also contain an $\mathrm{Mn}_{2} \mathrm{O}_{3}$ impurity. An examination of the XRD patterns before and after storage (Figure 9) show less peak broadening after storage for the more heavily substituted materials than for those containing less Ti. This is reflected in the good cycling behavior at both room temperature and $55^{\circ} \mathrm{C}$ (Figure 10). As with the layered manganese oxides and LNMO, higher capacities are obtained at the elevated temperatures, indicating some kinetic 
limitations at room temperature. The cycling results indicate that Ti substitution in tunnel compounds offers protection against Mn dissolution and prevents their deterioration.

Although some care needs to be taken to prevent air oxidation of the Ti-substituted tunnel compounds after preparation, they appear to be more stable than layered manganese oxides with respect to storage-induced phenomena. While unoccupied tunnels in these materials are potentially large enough to accommodate water or other small molecules, there is no evidence of structural deterioration induced by insertion of neutral species. Under the conditions used in this study, in which the charging voltage was limited to prevent irreversible oxidation of cell components, the discharge capacities of the tunnel compounds is much lower than that of layered manganese oxides, LNMO, and LNCMO. Up to $180 \mathrm{mAh} / \mathrm{g}$ has recently been demonstrated, however, for some $\mathrm{Li}_{\mathrm{x}} \mathrm{Ti}_{\mathrm{y}} \mathrm{Mn}_{1-\mathrm{y}} \mathrm{O}_{2}$ compounds when the charging voltage is extended to $4.8 \mathrm{~V}$ [26]. If a suitably stable electrolyte can be found, the energy densities of these materials can be raised substantially. Their robustness makes them attractive for use in rugged applications such as hybrid electric vehicles. 


\section{Conclusions}

The behavior of several layered and tunnel-containing manganese oxides exposed

to electrolytic solution at $55^{\circ} \mathrm{C}$ for up to eight weeks was examined. The propensity towards

Mn dissolution was shown to be a strong function of structure, type and amount of substitution, among other factors. Formation of expanded solvate phases and exfoliation is also structurally determined, with $\mathrm{O} 2$ stacking arrangements and $\mathrm{O} 2 / \mathrm{O} 3$ intergrowths more likely to undergo these storage-related changes than $\mathrm{O} 3$ arrangements or tunnel compounds. The tendency towards solvate formation and Mn dissolution explains the cycling behavior of these cathode materials at room temperature and $55^{\circ} \mathrm{C}$. The most stable materials appear to be mixed transition metal layered oxides having $\mathrm{Mn}$ in the +4 oxidation state, and $\mathrm{Ti}$ substituted tunnel structures. 


\section{Acknowledgments}

This work was supported by the Assistant Secretary for Energy Efficiency and

Renewable Energy, Office of FreedomCAR and Vehicle Technologies of the U.S.

Department of Energy under contract no. DE-AC02-05CH11231. This work was also supported by the Korea Research Foundation Grant (M01-2004-000-20008-0) (YJP).

\section{References}

1. E. I. Wang, U.S. Pat. 5,783,328 1998.

2. Y.-K. Sun, Y.-S. Lee, M. Yoshio, K. Amine, Electrochem. Solid-State Lett. 5 (2002)

A99-A102.

3. J. Cho, G. B. Kim, H. D. Lim, C. Kim, S. Yoo, Electrochem. Solid-State Lett. 2 (1999)

607-609.

4. W. Xu, C. A. Angell, Electrochem. Solid-State Lett. 4 (2001) E1-E4 .

5. K. Xu, S. Zhang, B. A. Poese, T. R. Jow, Electrochem. Solid-State Lett. 5 (2002)

A259-A262.

6. K. Xu, S. Zhang, and T. R. Jow, Electrochem. Solid-State Lett. 5 (2002) A26- 
A29.

7. H. Kitao, T. Fujihara, K. Takeda, N. Nakanishi, T. Nohma, Electrochem. and

Solid State Lett. 8 (2005) A87-A90.

8. M. M. Doeff, International Battery Association/Hawaii Battery Conference 2003, Waikoloa, HI, January 2003, p. 85.

9. M. M. Doeff, T. J. Richardson, K-T. Hwang, J. Power Sources 135 (2004) 240248.

10. M. Dollé, S. Patoux, and M. M. Doeff, Chem. Mater. 17 (2005) 1036-1043.

11. S. Patoux, M. Dollé, and M. M. Doeff, Chem. Mater. 17 (2005) 1044-1054.

12. M. M. Thackeray, J. Am. Ceram. Soc. 82 (1999) 3347-3354.

13. M.S. Islam, R.A. Davies, J.D. Gale, Chem. Mater. 15 (2003) 4280-4286.

14. B.J. Hwang, Y.W. Tsai, D. Carlier, G. Ceder, Chem. Mater. 15 (2003) 3676-3682.

15. J. Reed, G. Ceder, Electrochem. Solid-State Lett. 5 (2002) A145-A148.

16. C.S. Johnson, J.-S. Kim, A.J. Kropf, A.J. Kahaian, J.T. Vaughey, L.M.L. Fransson, K.

Edstrom, M.M. Thackeray, Chem. Mater. 15 (2003) 2313-2322.

17. J. Akimoto, Y. Takahashi, N. Kijima, Electrochem. and Sol. State Lett. 8 
(2005) A361-A364.

18. A. Du Pasquier, A. Blyr, P. Courjal, D. Larcher, G. Amatucci, B. Gérand, J.-M.

Tarascon J. Electrochem. Soc. 146 (1999) 428-436.

19. S. J. Wen, T. J. Richardson, L. Ma, K. A. Striebel, P. N. Ross, Jr., E. J. Cairns, J. Electrochem. Soc. 143 (1996) L136-L138.

20. H. Kobayashi, H. Sakaebe, K. Komoto, H. Kageyama, M. Tabuchi, K. Tatsumi, T. Kohigashi, M. Yonemura, R. Kanno, and T. Kamiyama Sol. State Ionics 156 (2003) 309-318.

21. F. T. Quinlan, K. Sano, T. Willey, R. Vidu, K. Tasaki, P. Stroeve Chem. Mater. 13 (2001) 4207-4212.

22. T. A. Eriksson, Y. J. Lee, J. Hollingsworth, J. A. Reimer, E. J. Cairns, X.-F. Zhang, M. M. Doeff, Chem. Mater. 15 (2003) 4456-4463.

23. J. Reed, G. Ceder, Chem. Rev. 104 (2004) 4513-4534.

24. M. M. Doeff, J. Hollingsworth, J. Shim, Y. J. Lee, K Striebel, J. A. Reimer, E.

J. Cairns, J. Electrochem. Soc. 150 (2003) A1060-A1066.

25. M. M. Doeff, A. Anapolsky, L. Edman, T. J. Richardson, L.C. De Jonghe, J. 
Electrochem. Soc. 148 (2001) A230-A236.

26. J. Akimoto, J. Awaka, Y. Takahashi, N. Kijima, M. Tabuchi, A. Nakashima, H.

Sakaebe, K. Tatsumi, Electrochem. and Sol. State Lett. 8 (2005) A554-A557. 
Table 1. Physical characteristics of compounds used in this study

\begin{tabular}{|c|c|c|c|c|}
\hline Compound & Source & Structure & $\mathrm{N}$ in $\mathrm{Mn}^{\mathrm{n}+}$ & $\begin{array}{l}\text { Surface area } \\
\mathrm{M}^{2} / \mathrm{g}\end{array}$ \\
\hline $\begin{array}{l}\text { LNMO } 30401 \\
\mathrm{Li}_{1.03} \mathrm{Ni}_{0.51} \mathrm{Mn}_{0.5} \mathrm{O}_{2}\end{array}$ & $\begin{array}{l}\text { Tanaka Chemical } \\
\text { Corporation }\end{array}$ & Layered $\mathrm{O} 3$ & 4.0 & $\sim 2 \mathrm{M}^{2} / \mathrm{g}$ \\
\hline $\begin{array}{l}\text { LNCMO } 30301 \\
\mathrm{Li}_{1.055} \mathrm{Ni}_{0.334} \mathrm{Co}_{0.336} \mathrm{Mn}_{0.334} \mathrm{O}_{2}\end{array}$ & $\begin{array}{l}\text { Tanaka Chemical } \\
\text { Corporation }\end{array}$ & Layered $\mathrm{O} 3$ & 4.0 & $\sim 0.8 \mathrm{M}^{2} / \mathrm{g}$ \\
\hline $\begin{array}{l}\text { Selectipur SP30 } \\
\mathrm{Li}_{1+\mathrm{x}} \mathrm{Mn}_{2-\mathrm{x}} \mathrm{O}_{4} \quad(\mathrm{x} \approx 0.03-0.06)\end{array}$ & EM Industries & spinel & $3.54-3.56$ & $4 \mathrm{M}^{2} / \mathrm{g}^{\mathrm{a}}$ \\
\hline $\mathrm{Li}_{0.484} \mathrm{Na}_{0.067} \mathrm{MnO}_{2.02}$ & Made in-house & Layered $\mathrm{O} 2$ & 3.49 & $\sim 10-15 \quad \mathrm{M}^{2} / \mathrm{g}$ \\
\hline$(\mathrm{Li}, \mathrm{Na})_{0.55} \mathrm{Mn}_{0.96} \mathrm{Al}_{0.04} \mathrm{O}_{2}{ }^{\mathrm{b}}$ & Made in-house & $\begin{array}{l}\mathrm{O} 2 / \mathrm{O} 3 \text { inter- } \\
\text { growth }\end{array}$ & $\sim 3.47$ & $\sim 10-15 \mathrm{M}^{2} / \mathrm{g}$ \\
\hline$(\mathrm{Li}, \mathrm{Na})_{0.45} \mathrm{Mn}_{0.9} \mathrm{Al}_{0.1} \mathrm{O}_{2}{ }^{\mathrm{b}}$ & Made in-house & Layered $\mathrm{O} 3$ & $\sim 3.61$ & $\sim 10-15 \quad \mathrm{M}^{2} / \mathrm{g}$ \\
\hline $\mathrm{Li}_{0.36} \mathrm{MnO}_{2}{ }^{\mathrm{b}}$ & Made in-house & Tunnel & $\sim 3.64$ & $\sim 2.0$ \\
\hline $\mathrm{Li}_{0.46} \mathrm{Ti}_{0.11} \mathrm{Mn}_{0.89} \mathrm{O}_{2}{ }^{\mathrm{b}}$ & Made in-house & Tunnel & $\sim 3.48$ & $\sim 1.7$ \\
\hline $\mathrm{Li}_{0.44} \mathrm{Ti}_{0.22} \mathrm{Mn}_{0.78} \mathrm{O}_{2}{ }^{\mathrm{b}}$ & Made in-house & Tunnel & $\sim 3.44$ & $\sim 1.8$ \\
\hline $\mathrm{Li}_{0.44} \mathrm{Ti}_{0.33} \mathrm{Mn}_{0.67} \mathrm{O}_{2}^{\mathrm{b}}$ & Made in-house & Tunnel & $\sim 3.34$ & $\sim 2.2$ \\
\hline $\mathrm{Li}_{0.44} \mathrm{Ti}_{0.44} \mathrm{Mn}_{0.56} \mathrm{O}_{2}{ }^{\mathrm{b}}$ & Made in-house & Tunnel & $\sim 3.21$ & $\sim 1.8$ \\
\hline
\end{tabular}

a) value taken from specification sheet supplied with sample

b) Estimated composition 


\section{Figure Captions}

Figure 1. Results of Mn strip tests on powders stored in electrolytic solution at $55^{\circ} \mathrm{C}$ for up to 8 weeks, categorized by general structure; see table 1 for exact chemical formulas.

Figure 2. $\mathrm{XRD}$ powder patterns of (a) $\mathrm{O} 2-\mathrm{Li}_{0.484} \mathrm{Na}_{0.067} \mathrm{MnO}_{2.02}$, (b) $\mathrm{O} 2 / \mathrm{O} 3-(\mathrm{Li}$, $\mathrm{Na})_{0.55} \mathrm{Mn}_{0.96} \mathrm{Al}_{0.04} \mathrm{O}_{2}$, and (c) O3-(Li,Na) $0.45 \mathrm{Mn}_{0.9} \mathrm{Al}_{0.1} \mathrm{O}_{2}$, freshly prepared and dried (bottom of each plot), after exposure to the atmosphere (middle of each plot) and after storage in electrolytic solution at $55^{\circ} \mathrm{C}$ for eight weeks (top of each plot). The reflections from a $\mathrm{P} 2-\mathrm{Na}_{0.7} \mathrm{MnO}_{2}(\mathbf{\square})$ precursor, solvates or hydrates $(*), \mathrm{Li}_{2} \mathrm{CO}_{3}(\mathbf{O})$, and an unknown decomposition product (?) are marked. Al from the sample holder is also indicated.

Figure 3. FTIR spectra of $\mathrm{O} 3-(\mathrm{Li}, \mathrm{Na})_{0.45} \mathrm{Mn}_{0.9} \mathrm{Al}_{0.1} \mathrm{O}_{2}$, after exposure to air (bottom) and after storage in electrolytic solution at $55^{\circ} \mathrm{C}$ for eight weeks (top). Peaks at 1498, 1442, 1090 and $870 \mathrm{~cm}^{-1}$ belonging to $\mathrm{Li}_{2} \mathrm{CO}_{3}$ are marked $(\bigcirc)$. The peak at $1636 \mathrm{~cm}^{-1}$ in both spectra can be assigned to adventitious water. Peaks at 1296, 1150, 1016 and $903 \mathrm{~cm}^{-1}$ in the top spectrum can be assigned to components of the electrolytic solution or SEI layer.

Figure 4. Cycling data at room temperature and $55^{\circ} \mathrm{C}$ for lithium cells containing layered manganese oxides: (a) $\mathrm{O} 2-\mathrm{Li}_{0.484} \mathrm{Na}_{0.067} \mathrm{MnO}_{2.02}$, (b) $\mathrm{O} 2 / \mathrm{O} 3-(\mathrm{Li}, \mathrm{Na})_{0.55} \mathrm{Mn}_{0.96} \mathrm{Al}_{0.04} \mathrm{O}_{2}$, and (c) O3-(Li,Na) ${ }_{0.45} \mathrm{Mn}_{0.9} \mathrm{Al}_{0.1} \mathrm{O}_{2}$. Discharges were carried out at $0.16 \mathrm{~mA} / \mathrm{cm}^{2}$ between 4.5-2.0V 
Figure 5. XRD powder pattern of (a) $\mathrm{Li}_{1.03} \mathrm{Ni}_{0.51} \mathrm{Mn}_{0.5} \mathrm{O}_{2}$ (LNMO) with inset showing the low angle region, and (b) $\mathrm{Li}_{1.055} \mathrm{Ni}_{0.334} \mathrm{Co}_{0.336} \mathrm{Mn}_{0.334} \mathrm{O}_{2}$ (LNCMO), before (bottom of each plot) and and after (top of each plot) storage in electrolytic solution at $55^{\circ} \mathrm{C}$. Reflections attributable to solvate phases are marked $\left(^{*}\right)$ and an unknown phase is indicated with a question mark.

Figure 6. FTIR spectra of $\mathrm{Li}_{1.055} \mathrm{Ni}_{0.334} \mathrm{Co}_{0.336} \mathrm{Mn}_{0.334} \mathrm{O}_{2}$ (LNCMO) prior to storage (bottom) and after (top) storage in electrolytic solution at $55^{\circ} \mathrm{C}$ for eight weeks. See text for peak assignments.

Figure 7. Cycling data at room temperature and $55^{\circ} \mathrm{C}$ for lithium cells containing (a) $\mathrm{Li}_{1.03} \mathrm{Ni}_{0.51} \mathrm{Mn}_{0.5} \mathrm{O}_{2}$ (LNMO) and (b) $\mathrm{Li}_{1.055} \mathrm{Ni}_{0.334} \mathrm{Co}_{0.336} \mathrm{Mn}_{0.334} \mathrm{O}_{2}$ (LNCMO). Discharges were carried out at $0.28 \mathrm{~mA} / \mathrm{cm}^{2}$ between $4.3-2.5 \mathrm{~V}$.

Figure 8. (a) XRD powder pattern of $\mathrm{Li}_{0.36} \mathrm{MnO}_{2}$ before (bottom) and after (top) storage in electrolytic solution at $55^{\circ} \mathrm{C}$ for two weeks. $\mathrm{An} \mathrm{Mn}_{2} \mathrm{O}_{3}$ impurity is marked (A). (b) Expansion of the mid-angle region of the pattern in (a), showing peak broadening after storage.

Figure 9. $\mathrm{XRD}$ patterns of (a) $\mathrm{Li}_{0.46} \mathrm{Ti}_{0.11} \mathrm{Mn}_{0.89} \mathrm{O}_{2}$ (b) $\mathrm{Li}_{0.44} \mathrm{Ti}_{0.22} \mathrm{Mn}_{0.78} \mathrm{O}_{2}$ (c) $\mathrm{Li}_{0.44} \mathrm{Ti}_{0.33} \mathrm{Mn}_{0.67} \mathrm{O}_{2}$ and (d) $\mathrm{Li}_{0.44} \mathrm{Ti}_{0.44} \mathrm{Mn}_{0.56} \mathrm{O}_{2}$ before (bottom of each plot) and after (top of each plot storage in electrolytic solution at $55^{\circ} \mathrm{C}$ for eight weeks. 
Figure 10. Cycling data at room temperature and $55^{\circ} \mathrm{C}$ for lithium cells containing tunnel compounds: (a) $\mathrm{Li}_{0.46} \mathrm{Ti}_{0.11} \mathrm{Mn}_{0.89} \mathrm{O}_{2}$, (b) $\mathrm{Li}_{0.44} \mathrm{Ti}_{0.22} \mathrm{Mn}_{0.78} \mathrm{O}_{2}$ (c) $\mathrm{Li}_{0.44} \mathrm{Ti}_{0.33} \mathrm{Mn}_{0.67} \mathrm{O}_{2}$, and (d) $\mathrm{Li}_{0.44} \mathrm{Ti}_{0.44} \mathrm{Mn}_{0.56} \mathrm{O}_{2}$. Discharges were carried out at $0.11 \mathrm{~mA} / \mathrm{cm}^{2}$ between $4.3-2.5 \mathrm{~V}$. 


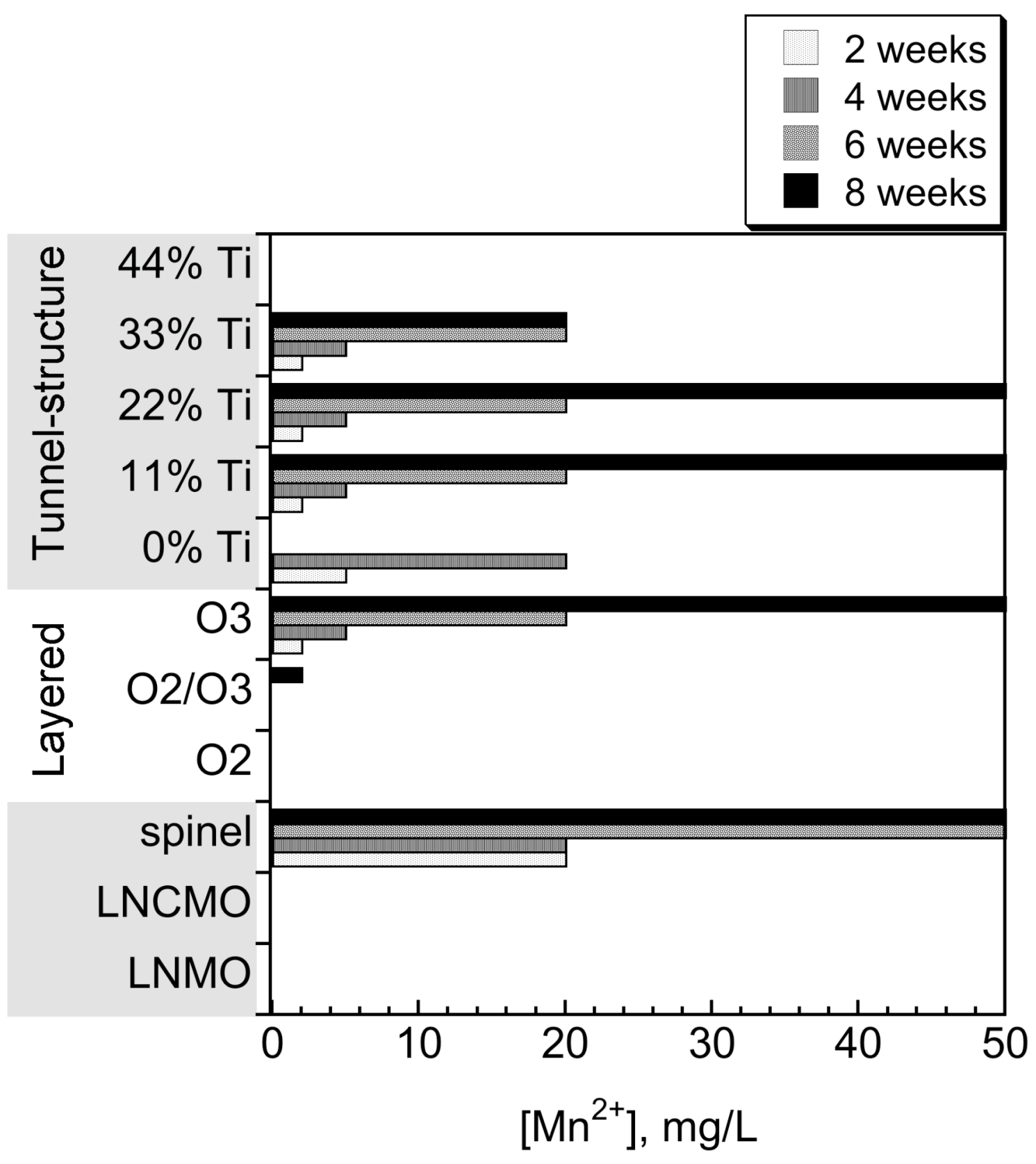

Figure 1 
(a)

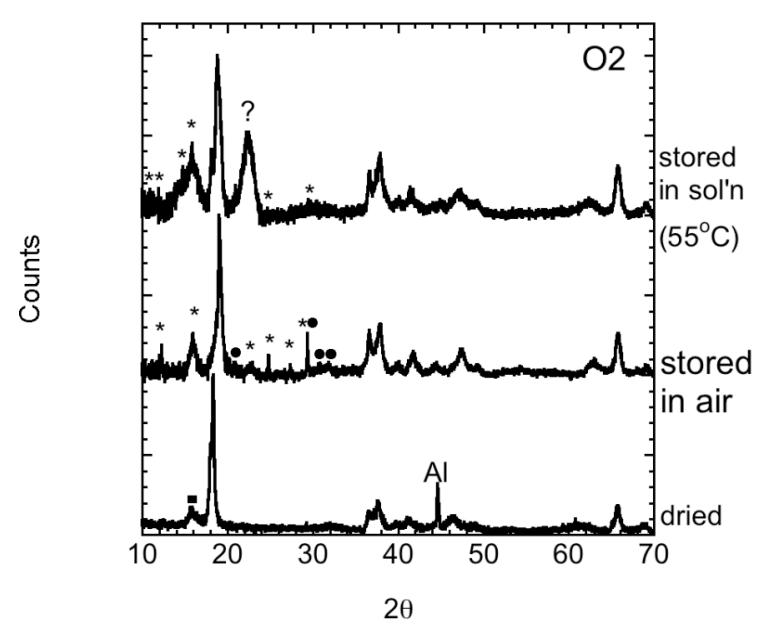

(b)
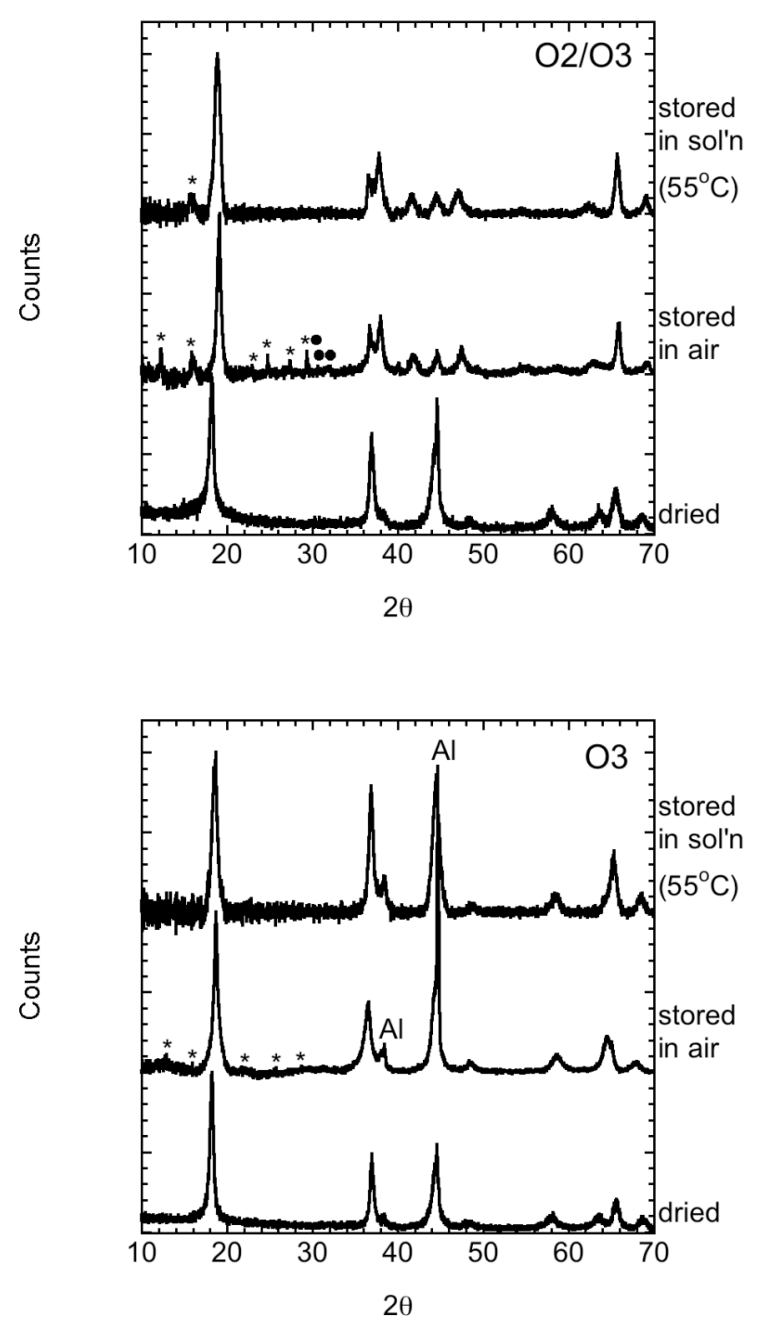

Figure 2 


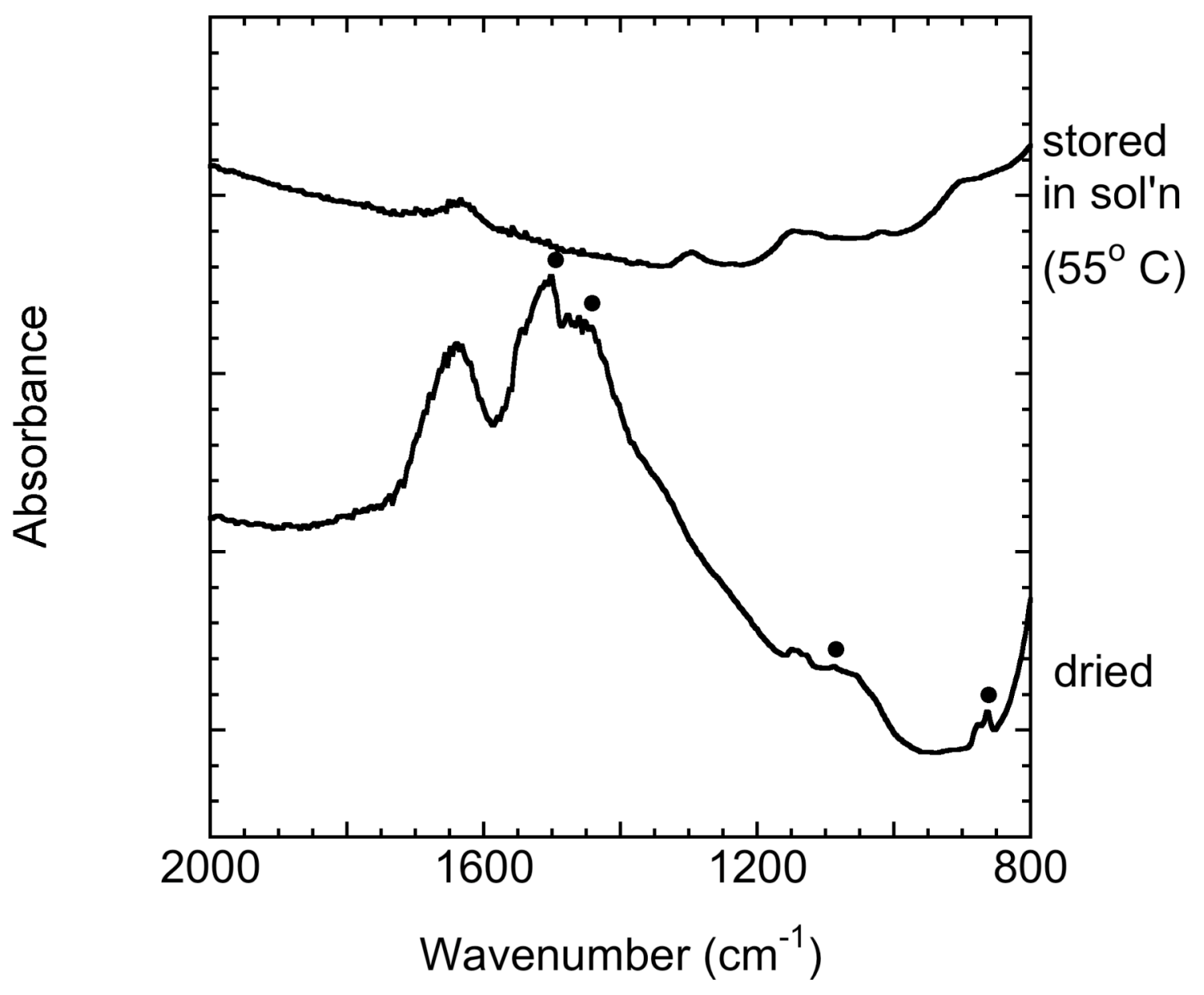

Figure 3 
(a)

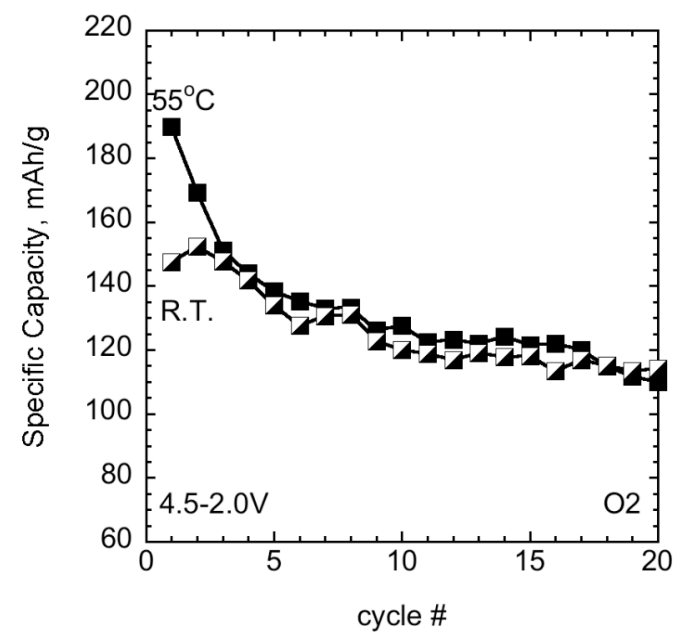

(b)

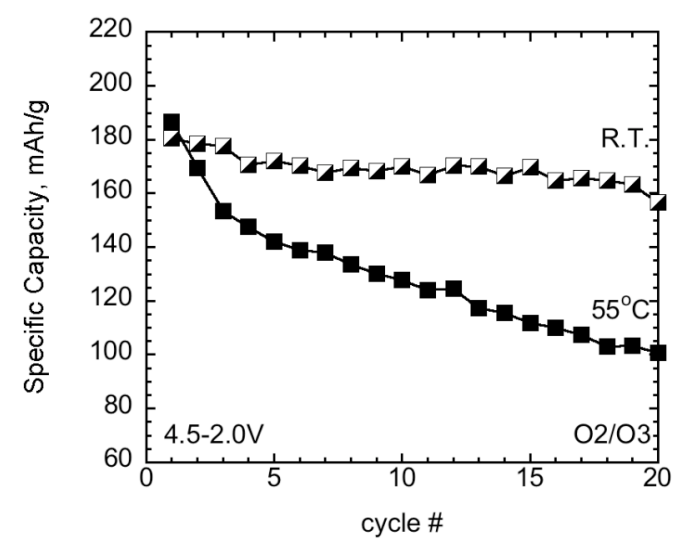

(c)

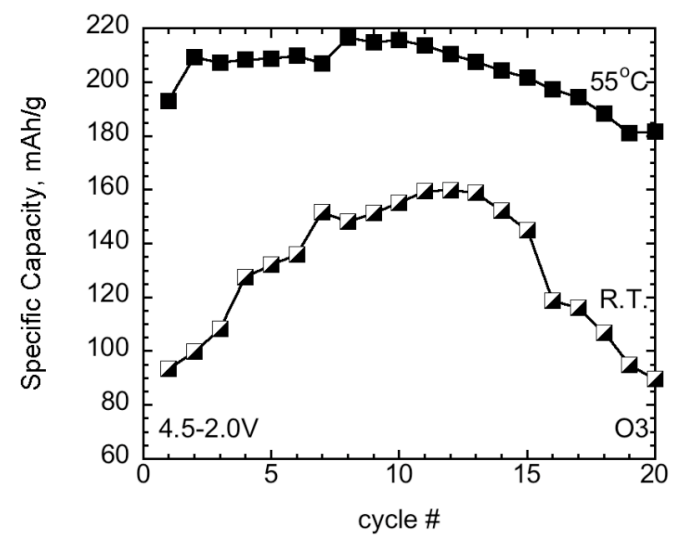

Figure 4 
(a)
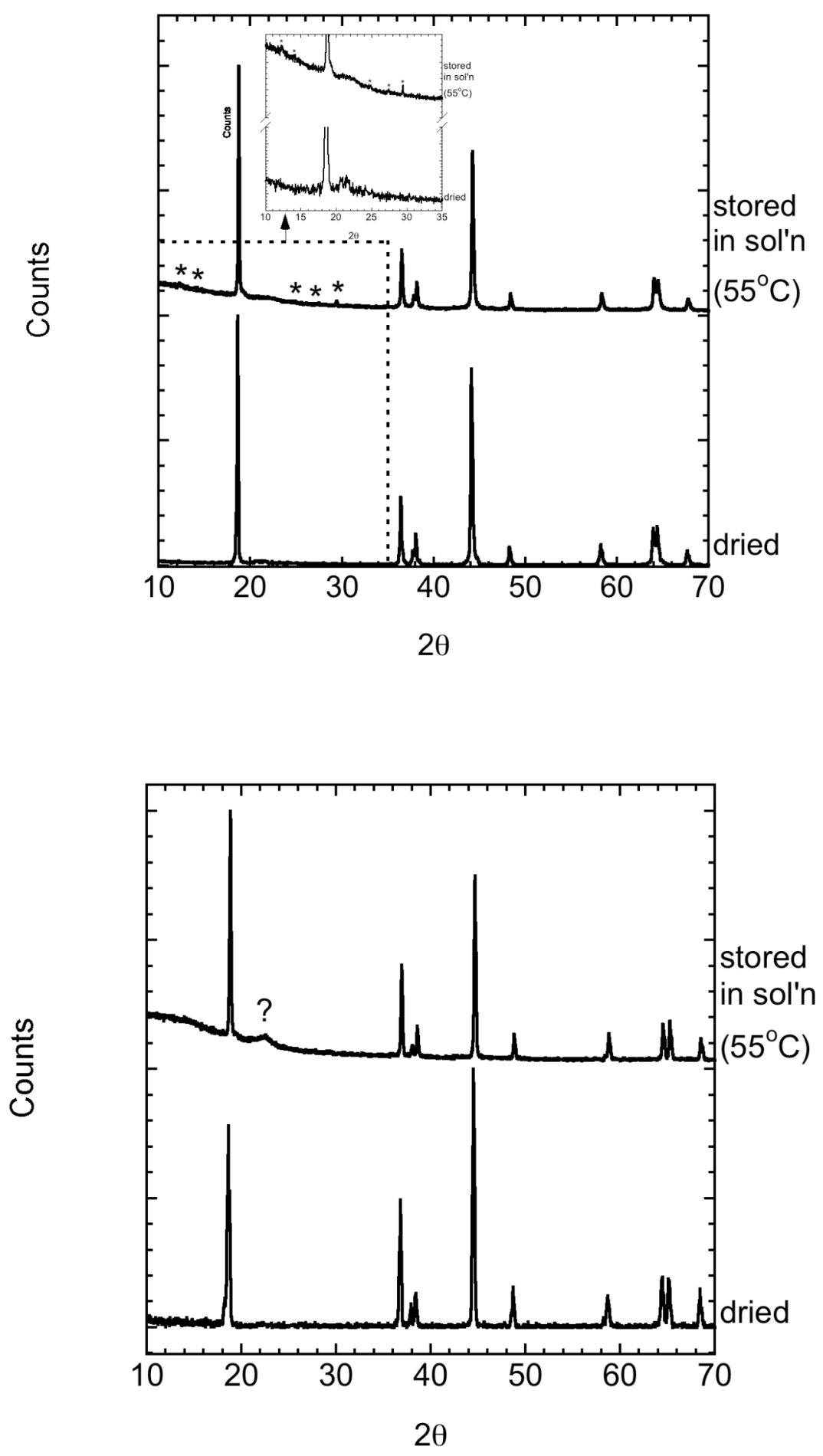

Figure 5 


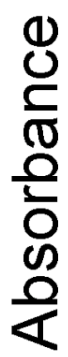

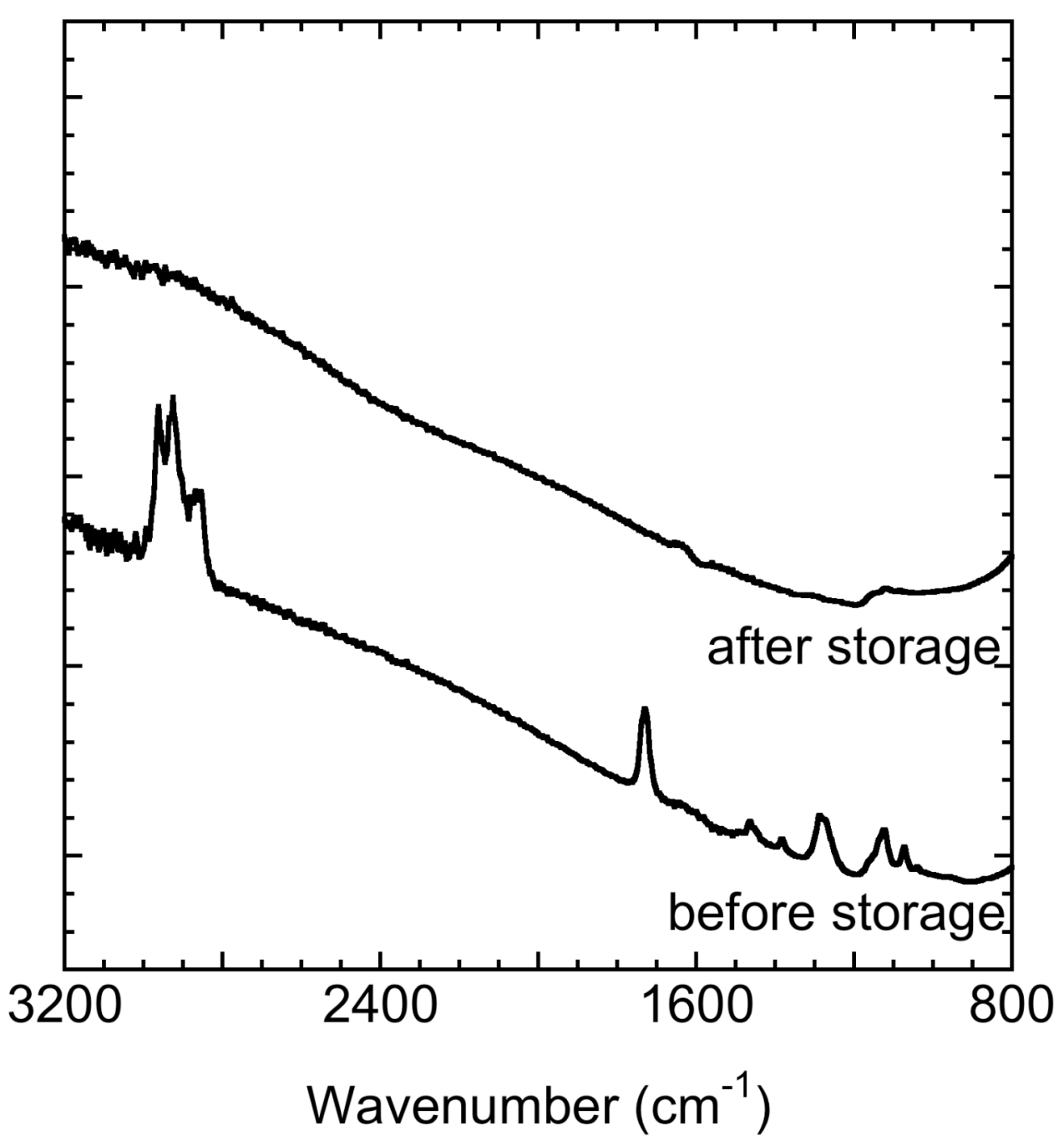

Figure 6 
(a)
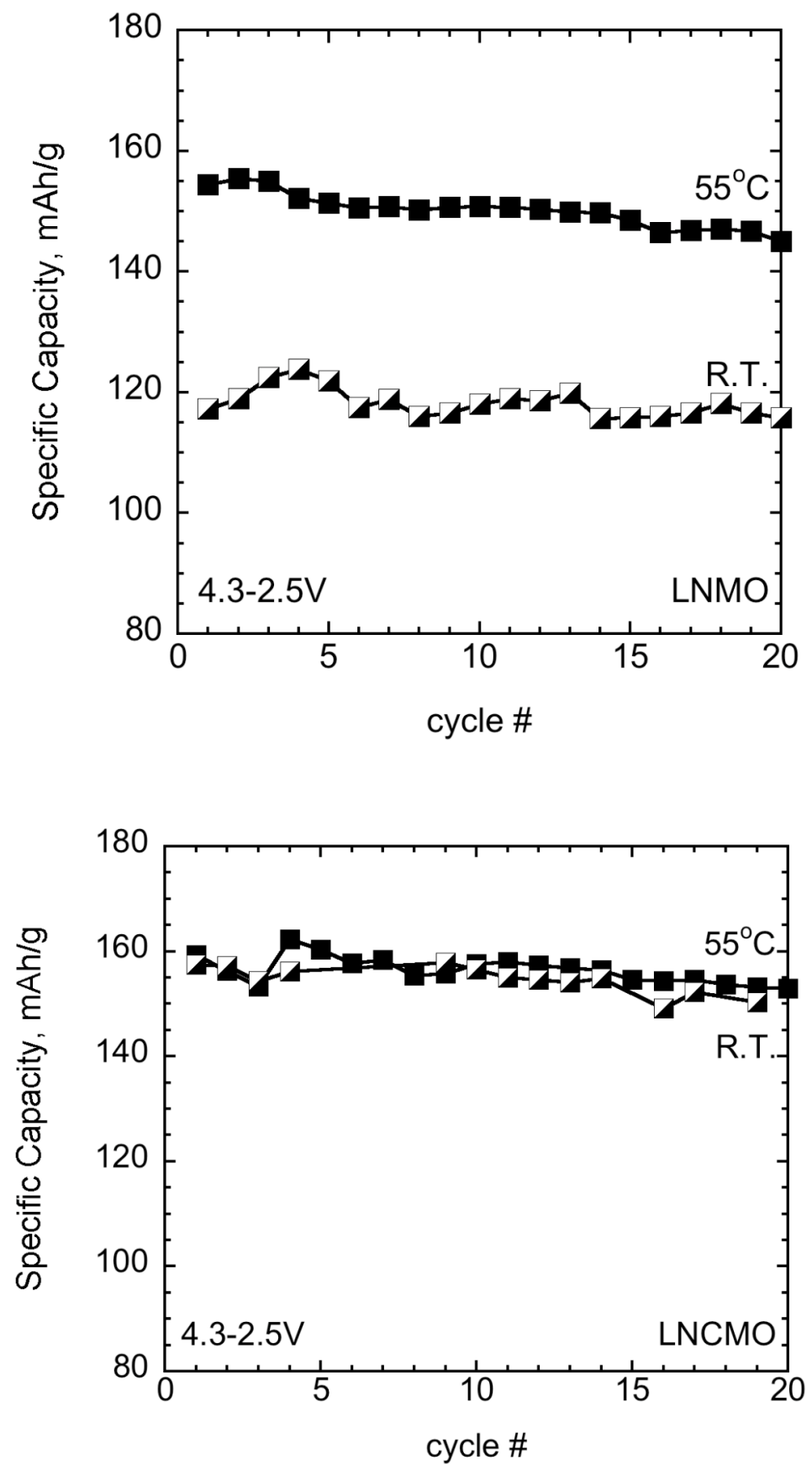

(b)

Figure 7 
(a)
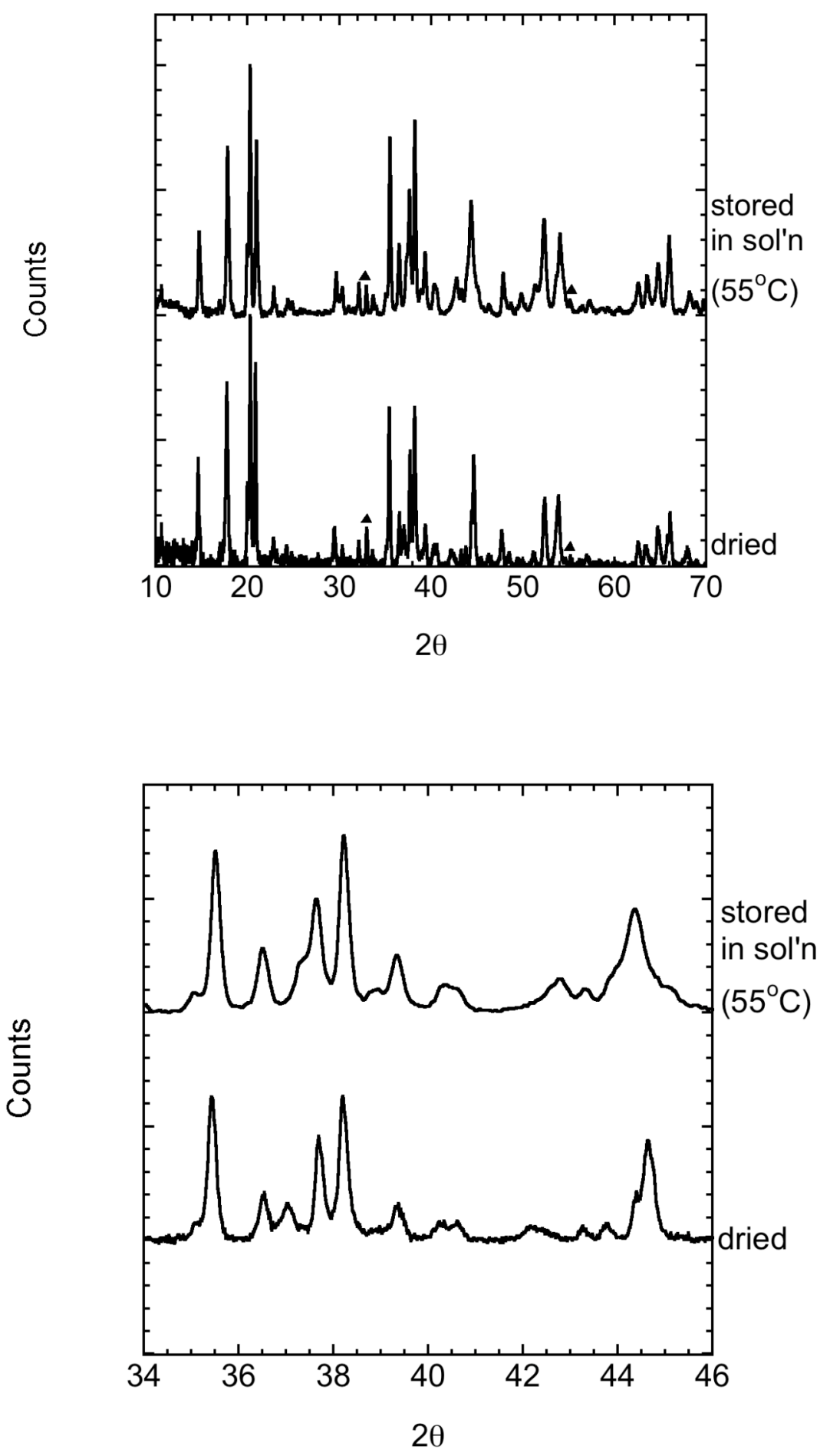

Figure 8 


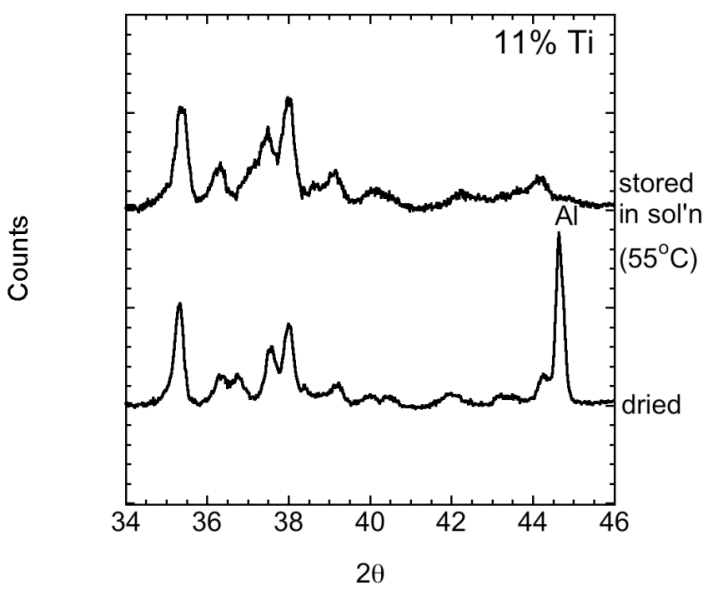

(a)

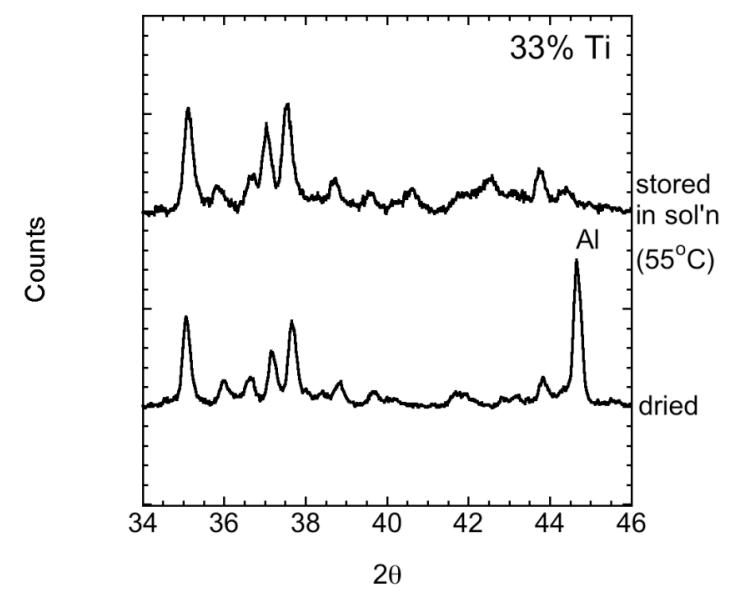

(c)

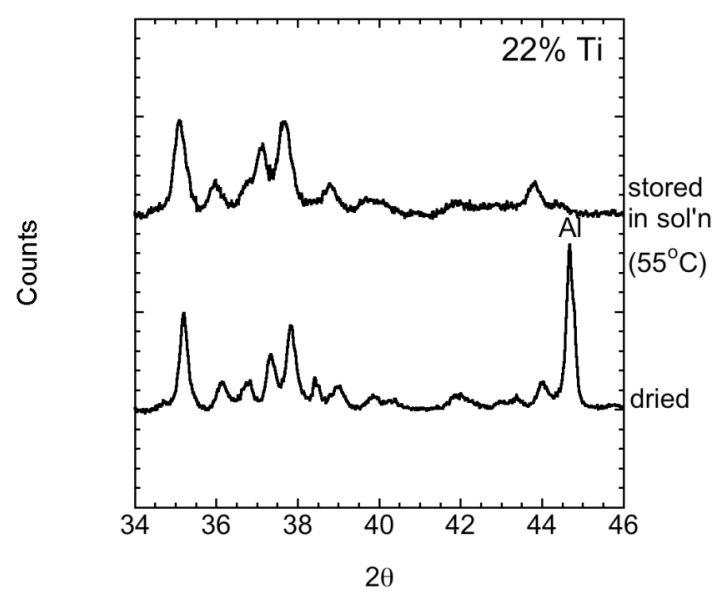

(b)

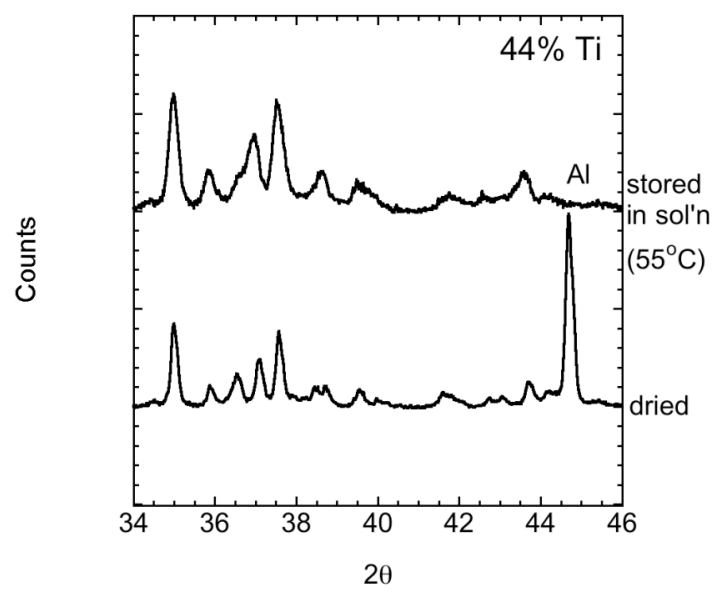

(d)

Figure 9 


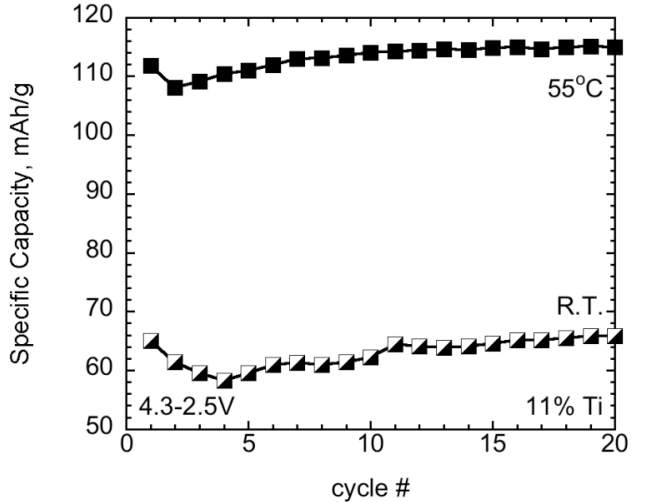

(a)

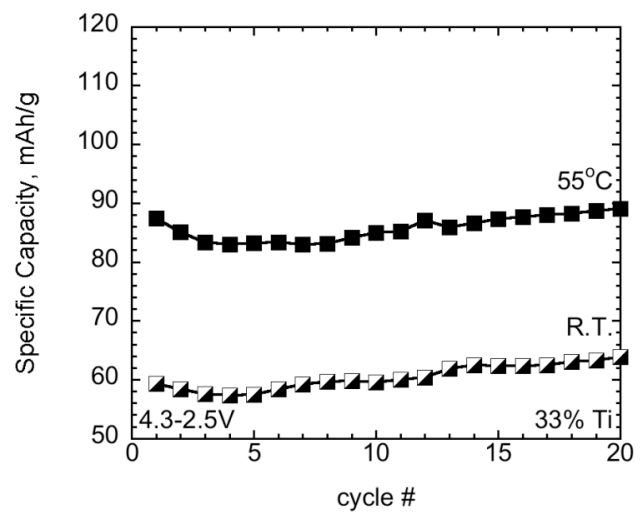

(c)

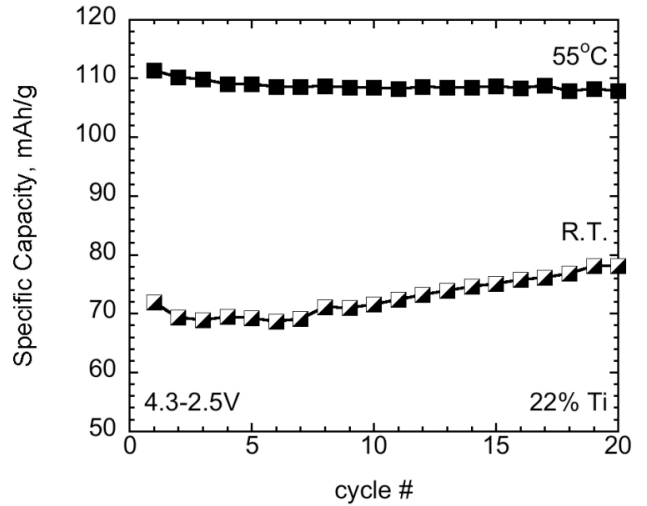

(b)

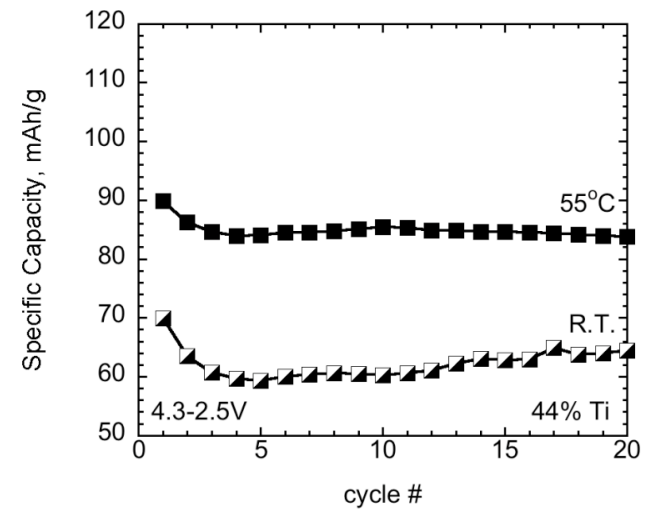

(d)

Figure 10 